\title{
Effects of medicinal herbs on osteoporosis: a systematic review based on clinical trials
}

\author{
Shahrzad Habibi Ghahfarrokhi ${ }^{1}$, Roya Reisi ${ }^{*^{*}}$ \\ ${ }^{1}$ Department of Social Medicine, Modeling in Health Research Center, Shahrekord University of Medical Sciences, Social \\ Determinants of Health Research Center, Shahrekord, Iran \\ ${ }^{2}$ Hamadan University of Medical Sciences, Hamadan, Iran
}

*Corresponding Author: Roya Reisi, School of Medicine, Besat Hospital, Hamadan University of Medical Sciences, Email: r_reisi2@yahoo.com, Tel: 09131841063

\begin{abstract}
Osteoporosis is rapidly turning into a global epidemic, leading to high rates of morbidity and mortality due to the resulting complications such as osteoporotic fractures in older people. Therefore, this review investigated the findings of clinical trials regarding the effects of medicinal herbs on osteoporosis. To this end, several keywords were used to search for relevant articles indexed in the Institute for Scientific Information and PubMed, including "Osteoporosis" or "Bone loss" AND "medicinal plant" or "phyto*" or "herb*". Finally, 43 articles were included in the review. There are several mechanisms for anti-osteoporosis effects. Estrogen-like effects, especially soy phytoestrogenic compounds and other herbal compounds and formulations, can enhance bone formation markers, as well as antioxidant and anti-inflammatory capacity, while decreasing bone resorption biomarkers. Therefore, they can be used as complementary medicine for osteoporosis, especially in postmenopausal older women. However, for more reliable evidence, further studies are still needed because most studies have addressed soy, and the number of randomized controlled trials conducted on other herbal drugs is small. The plants possess the androgen-like properties that play an important role in the promotion of bone health. In addition, herbal treatments are supportive and slow-acting and thus such treatments are suggested for prevention and maintenance purposes rather than fast-acting treatments.

Keywords: Medicinal herbs, Osteoporosis, Bone loss, Phytoestrogen
\end{abstract}

Received: 30 Jun 2019, Accepted: 13 Jul 2019, ePublished: 30 October 2019

\section{Introduction}

Osteoporosis is considered a serious growing health issue that causes many osteoporotic fractures globally each year due to impaired bone quality (1). In addition, osteoporosis is responsible for impaired stem cell differentiation and impaired bone microarchitecture/mineralization, especially in older women (2). Although this disease can be clinically silent and the people do not usually undergo screening and prevention measures for it, the cost of osteoporotic fractures imposes a heavy burden on the healthcare system $(3,4)$. The disease also substantially decreases the quality of life in patients and elder women (5). Further, osteoporosis is a multifactorial disorder and its risk factors include age over 65 years, postmenopausal estrogen loss or age associated with the deterioration of the microarchitecture, along with the family history of fracture, smoking, obesity, and low body mass index. The disease has also secondary risk factors that encompass underlying disorders and the use of certain drugs (2). Therefore, several therapeutic strategies are available to fight the disease. Although there are several anti-osteoporotic drugs and treatments of choice for improving bone mineral density (BMD), numerous needs remain unmet and several side effects and treatment failures are also reported due to therapeutic methods $(6,7)$. Nowadays, the use of medicinal plants is growing for the treatment of various diseases. Fewer side effects, cost-effectiveness, and convenient access have positively contributed to the popularity of medicinal plantbased treatments (8). Although medicinal plants and their derivatives can effectively maintain the bone metabolism in a balanced state and increase lumbar spine BMD, herbal treatments have not come up with convincing outcomes regarding the treatment or prevention of osteoporosis $(9,10)$.

Many articles have acknowledged the therapeutic value of medicinal plants although these theories do not rely on reliable data from clinical trials. Therefore, the present review article evaluated the effects of medicinal plants on osteoporosis according to the results of clinical trials.

(C) 2019 The Author(s); Published by Shahrekord University of Medical Sciences. This is an open-access article distributed under the terms of the Creative Commons Attribution License (http://creativecommons.org/licenses/by/4.0), which permits unrestricted use, distribution, and reproduction in any medium, provided the original work is properly cited. 


\section{Materials and Methods}

To conduct this review article, keywords such as "Osteoporosis" or "Bone loss" AND "medicinal plant" or "phyto*" or "herb*" were utilized to search for relevant articles indexed in the Institute for Scientific Information and PubMed using the EndNote software. A standard form was also prepared, including items such as the author, the title or purpose of the study, medicinal plant or formulation(s) or constitute(s) names, the type of intervention, the dosage, the duration, outcome, publishing journal, and the number of co-authors. Then, the full texts of the articles that fulfilled the purpose of the review were included in the analysis after achieving the agreement of the co-authors, followed by recording the above-mentioned information in the form. Next, clinical trials conducted on osteoporosis were considered as the inclusion criteria. Moreover, the articles that had a positive effect on osteoporosis were included in the review. However, those articles reporting studies with non-positive effects, review articles, articles with inaccessible full texts, non-English language articles, and studies irrelevant to the main aim of the review were excluded after obtaining the agreement of all authors. Overall, 43 studies were included in the final analysis (Figure 1).

\section{Results}

The use of medicinal plant-based products and derivatives is considered as a convenient and cost-effective method for improving bone health. They even can be used as a food or dietary supplement to prevent postmenopausal osteoporosis. The interventions were reported to exert inflammatory and metabolic impacts, to decrease turnover markers and increase calcium conservation $(11,12)$. A

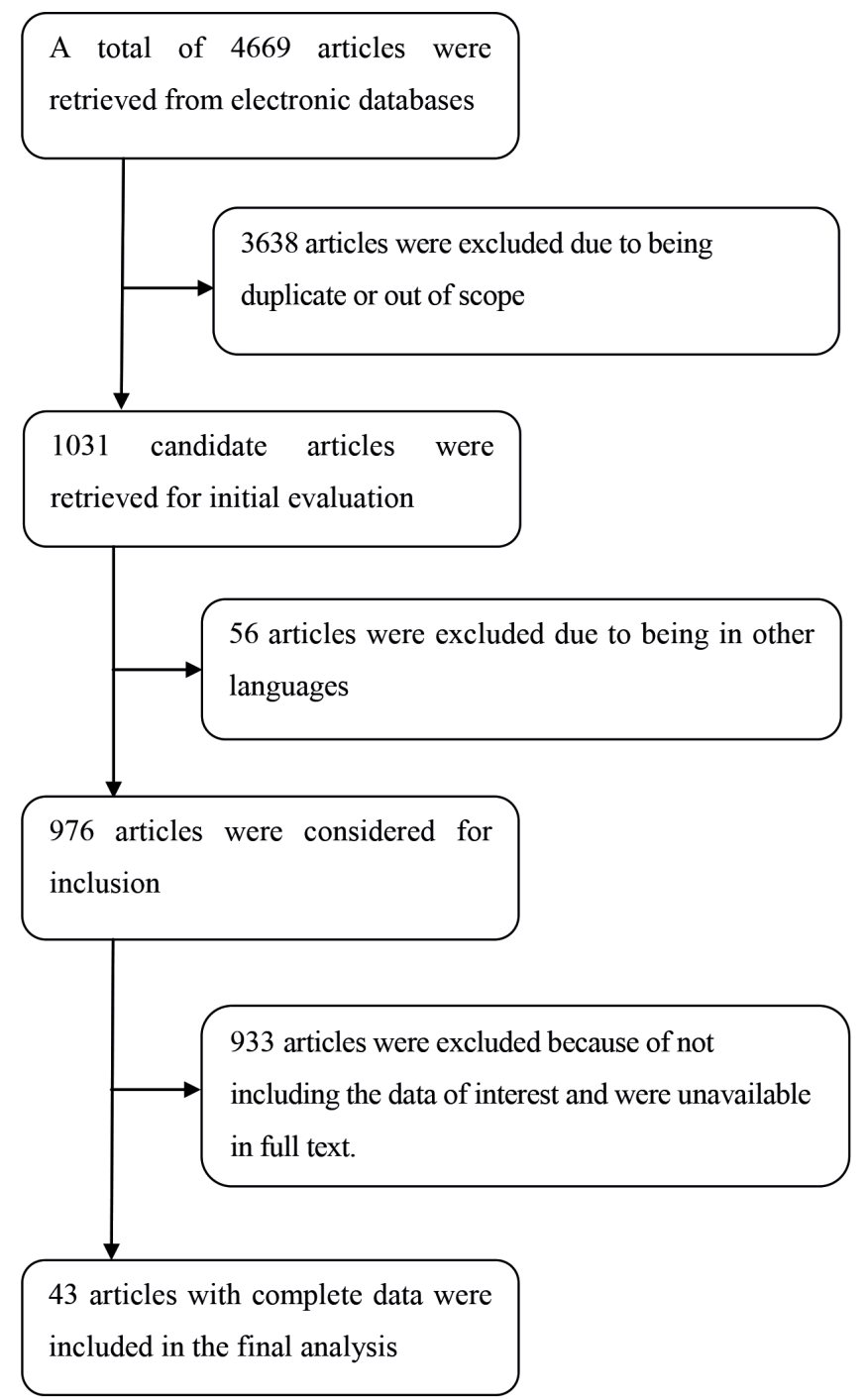

Figure 1. Flowchart of the Article Selection 
Table 1. Medicinal plants, formulations, and compounds with preventive and therapeutic effects against osteoporosis

\begin{tabular}{|c|c|c|c|c|}
\hline \multicolumn{5}{|c|}{ Medicinal Plants } \\
\hline Herbal Scientific Name & Dose/Duration & $\begin{array}{l}\text { Type of } \\
\text { Administration }\end{array}$ & Outcome & References \\
\hline Acanthopanax senticosus & $3 \mathrm{~g}$ per day for 6 months & Powder extract & $\begin{array}{l}\text { Have beneficial effects on bone } \\
\text { remodeling in postmenopausal women }\end{array}$ & Hwang et al (13) \\
\hline Trifolium pratense & $\begin{array}{l}150 \mathrm{~mL} \text { red clover extract containing } \\
37.1 \mathrm{mg} \text { isoflavones for } 12 \text { weeks }\end{array}$ & $\begin{array}{l}\text { Extract } \\
\text { supplementation }\end{array}$ & $\begin{array}{l}\text { Improved bone health in menopausal } \\
\text { women based on BMD and T-score }\end{array}$ & Thorup et al (14) \\
\hline
\end{tabular}

Medicinal Plant Formula

\begin{tabular}{|c|c|c|c|c|}
\hline Herbal Compound Name & Dose/Duration & $\begin{array}{l}\text { Type of } \\
\text { Administration }\end{array}$ & Outcome & References \\
\hline Kidney-tonifying prescription & $\begin{array}{l}25 \mathrm{~mL} \text { was taken twice daily for } 8 \\
\text { months }\end{array}$ & Dilution & $\begin{array}{l}\text { Significantly increased the level of } \\
\text { estradiol and BMD }\end{array}$ & Zhao et al (15) \\
\hline Yang Huo San Zi Tang & $\begin{array}{l}\text { Two Gaierqi D tablets as a daily dose for } \\
6 \text { months }\end{array}$ & Tablet & $\begin{array}{l}\text { Increased bone growth protein, BMD, } \\
\text { and estradiol after } 3 \text { and } 6 \text { months }\end{array}$ & Qiu et al (16) \\
\hline Yigu capsule & 4 capsules each time, 3 times a day & Capsule & $\begin{array}{l}\text { Increased the BMD, alleviated the rate } \\
\text { of ostealgia and inhibited the absorption } \\
\text { of bone while elevating the sex hormone } \\
\text { level }\end{array}$ & Zhang et al (17) \\
\hline Bo-gu Ling & $\begin{array}{l}6 \text { capsules ( } 380 \mathrm{mg} / \text { capsule) once daily } \\
\text { for } 12 \text { months }\end{array}$ & Capsule & $\begin{array}{l}\text { Improved BMD on the women who } \\
\text { experienced over } 10 \text { years of menopause }\end{array}$ & Leung et al (18) \\
\hline Yang tonic formula & $18 \mathrm{~g}$ twice daily for 6 months & Dilution & $\begin{array}{l}\text { Improved bone mass without adverse } \\
\text { effects }\end{array}$ & Yang et al (19) \\
\hline Xian Ling GuBao & 3 and 6 g/day for 1 year & Capsule & $\begin{array}{l}\text { Significantly increased BMD at } 6 \text { months } \\
\text { in a safe manner }\end{array}$ & Zhu et al (20) \\
\hline Qing'e formula & $\begin{array}{l}\text { For every } 100 \mathrm{~g} \text { of the powder } 50-70 \\
\mathrm{~g} \text { of refining honey was added for } \\
\text { producing the Qing'e pill. QEF was } \\
\text { administered three times daily with warm } \\
\text { water plus Caltrate and } 600 \mathrm{mg} \text { daily in } \\
\text { QEF+calcium group for } 6 \text { months }\end{array}$ & Supplementation & $\begin{array}{l}\text { Decreased the levels of C-telopeptide } \\
(\beta \text {-CTX), N-MID, and type I procollagen- } \\
\text { N-propeptide (P1NP) and modulated } \\
\text { bone metabolism in patients with } \\
\text { postmenopausal osteoporosis }\end{array}$ & Yang et al (21) \\
\hline QiangGuYin & $20 \mathrm{~g} /$ day for 12 months & $\begin{array}{l}\text { Concentrated } \\
\text { decoction }\end{array}$ & $\begin{array}{l}\text { Increased BMD while it decreased } \\
\beta-C T X \text { and P1NP }\end{array}$ & Shi et al. (22) \\
\hline $\begin{array}{l}\text { Linum usitatissimum + sesame } \\
\text { indicum + Cicer canaries and } \\
\text { palm pollen grain }\end{array}$ & 40 gr mixture seeds for 3 months & $\begin{array}{l}\text { Powder } \\
\text { supplementation }\end{array}$ & $\begin{array}{l}\text { Improved the BMD of postmenopausal } \\
\text { women who suffered from bone fragility }\end{array}$ & Alshafei et al (23) \\
\hline Xianling Gubao & 3 tablets twice a day for 12 weeks & Capsule & $\begin{array}{l}\text { Improved BMD and the level of blood } \\
\text { calcium while it decreased the level } \\
\text { of blood phosphorus and alkaline } \\
\text { phosphatase (AKP) }\end{array}$ & Guo et al (24) \\
\hline Fufang Xian Ling GuBao & Twice daily for 6 months & Capsule & $\begin{array}{l}\text { Prevented the corticosteroid-associated } \\
\text { osteonecrosis of the femoral head in } \\
\text { patients with immune-inflammatory }\end{array}$ & Li et al (25) \\
\hline Ziyin Jianghuo Ningxin & $\begin{array}{l}25 \text { mg was taken each time, twice per } \\
\text { day for } 3 \text { months }\end{array}$ & Capsule & $\begin{array}{l}\text { Improved BMD of postmenopausal } \\
\text { women }\end{array}$ & Lin et al (26) \\
\hline $\begin{array}{l}\text { Morus alba and Polygonum } \\
\text { odoratum }\end{array}$ & 2 doses of 50 and $1500 \mathrm{mg} / \mathrm{d}$ for 8 weeks & Extract & $\begin{array}{l}\text { Improved serum AKP, osteocalcin, and } \\
\text { total phenolic compound content but } \\
\text { decreased } \beta \text {-CTX level }\end{array}$ & $\begin{array}{l}\text { Wattanathorn et } \\
\text { al }(27)\end{array}$ \\
\hline Cheong-A-Won & 9 g 3 times a day for 24 weeks & Capsule & Significant increase in BMD and t-score & Yun et al. (28) \\
\hline Bushen Yijing Fang & $\begin{array}{l}0.55 \mathrm{~g} / \text { capsule, } 3 \text { capsules/time, } 3 \text { times/ } \\
\text { day for } 36 \text { months }\end{array}$ & Capsule & $\begin{array}{l}\text { Improved BMD and t-score in women } \\
\text { with osteopenia }\end{array}$ & Zheng et al (29) \\
\hline
\end{tabular}


Medicinal Plant Constitutes

\begin{tabular}{|c|c|c|c|c|}
\hline Herbal Derivative Name & Dose/Duration & $\begin{array}{l}\text { Type of } \\
\text { Administration }\end{array}$ & Outcome & References \\
\hline Soy isoflavone & $\begin{array}{l}12 \text { consecutive weeks with } 60 \mathrm{mg} / \mathrm{d} \text { of } \\
\text { isoflavones }\end{array}$ & Supplementation & $\begin{array}{l}\text { Increased serum levels of phytoestrogens } \\
\text { while it diminished several key clinical } \\
\text { risk factors for } \\
\text { osteoporosis in normal postmenopausal } \\
\text { women }\end{array}$ & Scheiber et al (30) \\
\hline Soy isoflavone & 2 meals twice a week with two meals & Supplementation & $\begin{array}{l}\text { Stimulates bone osteoblastic activity and } \\
\text { augmented in osteocalcin concentrations }\end{array}$ & Chiechi et al (31) \\
\hline Soy isoflavone & $\begin{array}{l}\text { Mid-dose ( } 40 \mathrm{mg} \text { ) and high-dose }(80 \mathrm{mg} \text { ) } \\
\text { for } 12 \text { months }\end{array}$ & Capsule & $\begin{array}{l}\text { Increased the maintenance of the } \\
\text { hip bone mineral content in later } \\
\text { menopause or those with lower body } \\
\text { weight or calcium intake }\end{array}$ & Chen et al (32) \\
\hline Soy isoflavone & $126 \mathrm{mg}$ isoflavones for 6 months & $\begin{array}{l}\text { Extract } \\
\text { powder }\end{array}$ & $\begin{array}{l}\text { Reduced bone loss possibly via the } \\
\text { inhibition of bone resorption in non- } \\
\text { obese postmenopausal women }\end{array}$ & Ye et al (33) \\
\hline Soy isoflavone & $\begin{array}{l}75 \mathrm{mg} \text { of isoflavone conjugates/day for } \\
1 \text { year }\end{array}$ & Supplementation & $\begin{array}{l}\text { Prevented the isoflavones on bone } \\
\text { loss and fat accumulation in early } \\
\text { postmenopausal women }\end{array}$ & Wu et al (34) \\
\hline Soy isoflavone & 80 or $120 \mathrm{mg} / \mathrm{d}$ for 3 years & Tablet & $\begin{array}{l}\text { Increased volumetric BMD in } \\
\text { postmenopausal women }\end{array}$ & Shedd et al (35) \\
\hline Soy isoflavone & $70 \mathrm{mg} / \mathrm{d}$ for 12 weeks & Supplementation & $\begin{array}{l}\text { Increased bone formation markers } \\
\text { such as serum bone-specific alkaline } \\
\text { phosphatase and osteocalcin }\end{array}$ & Lee et al (36) \\
\hline Soy isoflavone & $\begin{array}{l}20 \text { mg genistein and daidzein, two } \\
\text { capsules, meaning } 40 \mathrm{mg} \text { p.o. daily for } \\
1 \text { year }\end{array}$ & Capsule & $\begin{array}{l}\text { Affected BMD, bone resorption, and } \\
\text { bone metabolism in postmenopausal } \\
\text { women }\end{array}$ & Tit et al (37) \\
\hline Soy isoflavone and protein & $\begin{array}{l}15 \mathrm{~g} \text { soy protein with } 66 \mathrm{mg} \text { isoflavone } \\
\text { or } 15 \mathrm{~g} \text { soy protein alone, daily for } 6 \\
\text { months }\end{array}$ & Supplementation & Reduced $\bigotimes-C T X$ andP1NP & $\begin{array}{l}\text { Sathyapalan et } \\
\text { al (38) }\end{array}$ \\
\hline Soy phytoestrogens & $200 \mathrm{mg}$ daily for 2 years & Tablet & $\begin{array}{l}\text { Prevented bone loss and menopausal } \\
\text { symptoms in menopause women }\end{array}$ & Levis et al (39) \\
\hline Soy phytoestrogens & $35 \mathrm{~g}$ soy protein per day for 12 weeks & Supplementation & $\begin{array}{l}\text { Caused delay bone resorption and } \\
\text { prevented osteoporosis }\end{array}$ & Roudsari et al (40) \\
\hline Soy protein with isoflavones & $\begin{array}{l}99 \mathrm{mg} \text { of isoflavones in } 25.6 \mathrm{~g} \text { of soy } \\
\text { protein for } 1 \text { year }\end{array}$ & Supplementation & $\begin{array}{l}\text { Increased BMD in postmenopausal } \\
\text { women }\end{array}$ & Kok et al (41) \\
\hline Phytoestrogen genistein & $54 \mathrm{mg} / \mathrm{d}$ of genistein daily for 24 months & Supplementation & Increased BMD in genistein prescription & Marini et al (42) \\
\hline Phytoestrogen genistein & $54 \mathrm{mg} / \mathrm{d}$ of genistein daily for 12 months & Tablet & $\begin{array}{l}\text { Positive effect on bone and reduction of } \\
\text { cytogenetic biomarkers }\end{array}$ & $\begin{array}{l}\text { Atteritano et al } \\
(43)\end{array}$ \\
\hline Phytoestrogen genistein & $\begin{array}{l}54 \mathrm{mg} \text { of genistein aglycone daily for } 3 \\
\text { years }\end{array}$ & Tablet & $\begin{array}{l}\text { Had positive effects on bone formation } \\
\text { and osteopenia in postmenopausal } \\
\text { women }\end{array}$ & Marini et al (44) \\
\hline Phytoestrogen genistein & $54 \mathrm{mg} / \mathrm{d}$ daily for 2 years & Tablet & $\begin{array}{l}\text { Improved the phalanges ultrasound } \\
\text { parameters and prevented bone loss in } \\
\text { osteopenic postmenopausal women }\end{array}$ & $\begin{array}{l}\text { Atteritano et al } \\
(45)\end{array}$ \\
\hline Phytoestrogen genistein & 10 capsules/tablets per intervention & Supplementation & $\begin{array}{l}\text { Suppressed net bone resorption in } \\
\text { postmenopausal women }\end{array}$ & Weaver et al (46) \\
\hline Phytoestrogen genistein & $30 \mathrm{mg} / \mathrm{d}$ for 6 months & Capsule & $\begin{array}{l}\text { Prevented osteoporosis and reduced } \\
\text { fracture risk in postmenopausal women }\end{array}$ & Lappe et al (47) \\
\hline Phytoestrogen genistein & $\begin{array}{l}2 \text { doses of a genistein-rich soy } \\
\text { supplement and } 3 \text { doses of mixed } \\
\text { isoflavones in various proportions for } \\
50 \text { days }\end{array}$ & Supplementation & $\begin{array}{l}\text { Soy isoflavones were effective on bone- } \\
\text { preserving agents in postmenopausal } \\
\text { women and mixed isoflavones in their } \\
\text { natural ratios were more effective than } \\
\text { enriched genistein }\end{array}$ & $\begin{array}{l}\text { Pawlowski et al } \\
\text { (48) }\end{array}$ \\
\hline
\end{tabular}




\begin{tabular}{|c|c|c|c|c|}
\hline Genistein Aglycone & $54 \mathrm{mg} / \mathrm{d}$ for 2 years & Tablet & $\begin{array}{l}\text { It was useful not only in postmenopausal } \\
\text { osteopenia but also in women with } \\
\text { osteoporosis }\end{array}$ & Arcoraci et al (49) \\
\hline Tofupill/Femarelle (DT56a) & $\begin{array}{l}644 \mathrm{mg} / \mathrm{d} \text { DT56a (study group) or } 344 \\
\mathrm{mg} / \mathrm{d} \text { DT56a for } 12 \text { months }\end{array}$ & Supplementation & $\begin{array}{l}\text { Increased BMD without unwanted } \\
\text { estrogenic effect }\end{array}$ & Yoles et al (50) \\
\hline $\begin{array}{l}\text { Epimedium-Derived } \\
\text { Phytoestrogen Flavonoids }\end{array}$ & $\begin{array}{l}\text { A daily dose of } 60 \mathrm{mg} \text { lcariin, } 15 \mathrm{mg} \\
\text { Daidzein, and } 3 \mathrm{mg} \text { genistein for } 24 \\
\text { months }\end{array}$ & Capsule & $\begin{array}{l}\text { Prevented bone loss without resulting in } \\
\text { endometrium hyperplasia effect }\end{array}$ & Zhang et al (51) \\
\hline $\begin{array}{l}\text { Hop rho iso-alpha acids and } \\
\text { berberine }\end{array}$ & $\begin{array}{l}200 \mathrm{mg} \text { hop rho iso-alpha acids } 100 \\
\text { mg berberine sulfate trihydrate, } 500 \mathrm{IU} \\
\text { vitamin } \mathrm{D} 3 \text {, and } 500 \mu \mathrm{g} \text { vitamin } \mathrm{K} 1 \text { twice } \\
\text { daily for } 14 \text { weeks }\end{array}$ & Tablet & $\begin{array}{l}\text { Decreased serum osteocalcin and } \\
\text { concentrations, increased serum } \\
25 \text {-hydroxyvitamin D concentrations, } \\
\text { and increased serum insulin-like growth } \\
\text { factor I concentrations }\end{array}$ & Lamb et al (52) \\
\hline $\begin{array}{l}\beta \text {-cryptoxanthin plus } \\
\text { phytosterols }\end{array}$ & $\begin{array}{l}\mathrm{b}-\mathrm{Cx}(0.75 \mathrm{mg} / \mathrm{d}) \text { and PS }(1.5 \mathrm{~g} / \mathrm{d}) \text { for } 4 \\
\text { weeks }\end{array}$ & Supplementation & $\begin{array}{l}\text { Combination therapy decreased } \\
\text { bone turnover markers and the risk of } \\
\text { osteoporosis }\end{array}$ & Granado et al (53) \\
\hline
\end{tabular}

total of 52 articles were included in the final analysis after studying the articles by two of the co-authors and according to the inclusion and exclusion criteria.

Medicinal plants and their compounds can be effective against osteoporosis via various mechanisms of action (Table 1).

\section{Discussion}

In this study, medicinal plants were found to prevent or reduce the symptoms of osteoporosis through several mechanisms. Conversely, however, some studies showed that these natural medicines may not have an impact on this disease. For example, in the study of Brink et al., supplementation with $110 \mathrm{mg} / \mathrm{d}$ of soy isoflavone aglycone for one year in postmenopausal women failed to prevent postmenopausal bone loss or affect bone turnover (54). Similarly, another study indicated that $200 \mathrm{mg}$ of soy isoflavones daily for 2 years did not prevent bone loss in menopausal women (55). Consistently, some studies have reported that treatment with isoflavones (aglycone equivalents), Trifolium pratense extract, and semelil (Angipars W) could not prevent a decline in BMD and had no significant effect on bone biomarkers and thus bone health (56-59). According to previous studies and the present one, it seems that differences in the study populations and the lack of controlling for confounding factors such as soy or phytoestrogens consumption in the control group may have led to these inconsistencies. The concomitant treatments, the duration of the studies, and the administration route of the herbal compounds may have also contributed to these differences.

Based on the findings of this review study, there are several mechanisms for the effect of medicinal plants on osteoporosis. Osteoporosis is characterized by skeletal degeneration with a reduction in BMD and the deterioration of the microarchitecture of the bone tissue, which leads to a fracture (60). This disease is more prevalent in postmenopausal women than older men because these women are more likely to develop osteoporosis compared to men due to massive declines in estrogen levels during menopause, which can lead to an increase in the bone-resorption activity and a decline in bone formation $(61,62)$. Estrogenic compounds like phytoestrogens affect bone via promoting the production of calcitonin, lowering the sensitivity of bone mass to parathyroid hormone, reducing the calcium excretion from the kidney, and accelerating intestinal calcium resorption. Further, estrogen can directly influence the bone, which, in turn, can inhibit bone resorption and increase bone density (63). Another mechanism is the anti-inflammatory and antioxidant effects of medicinal plants. Furthermore, inflammation cytokines exert substantial impacts on bone loss and osteoporosis (2). Phytoestrogens are able to suppress the production of proinflammatory cytokines like tumor necrosis factor-alpha (TNF- $\alpha$ ), IL-1, IL-6, and IL-7 as well. This is why these proinflammatory cytokines are elevated in postmenopausal women (64). In addition, the antioxidant capacity of herbal drugs can serve to scavenge free radicals, leading to the inhibition of cyclooxygenase- 2 (COX-2) and TNF- $\alpha$ production and expression. This results in a decrease in the receptor activator of NF- $\kappa \beta$ ligand (RANKL) expression (RANKL-stimulated RAW 264.7 cells also in bone marrow-derived macrophages), leading to a decline in the osteoclast activity, which, finally, reduces bone loss (64-66).

Moreover, herbal drugs can promote bone formation markers such as AKP, serum 25-hydroxyvitamin D, bone Gla protein, and osteocalcin but decrease bone resorption markers like serum collagen type 1 and $\beta$-CTX. Figure 2 summarizes the most important mechanisms of medicinal plants and their derivatives reported in clinical trials.

Although plant compounds are considered natural, 


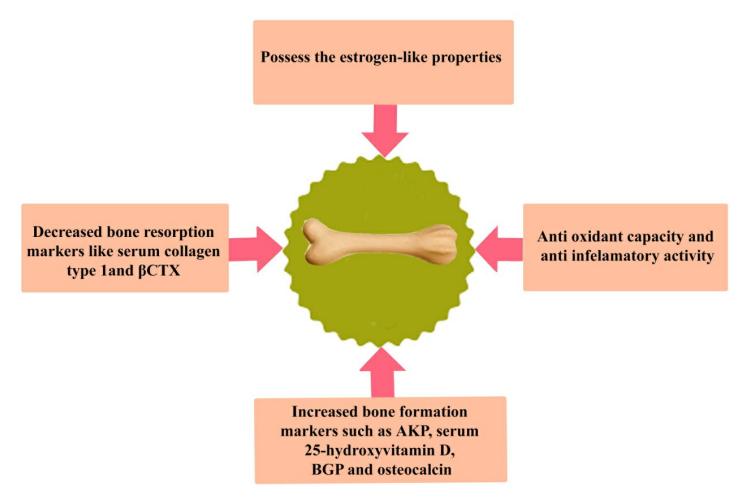

Figure 2. The most important mechanisms of medicinal plants and their derivatives.

they can lead to certain complications under certain circumstances such as the type of plant, dosage, and the duration of use. A meta-analysis demonstrated that the long-term consumption of phytoestrogens did not significantly increase the side effects such as endometrial hyperplasia, vaginal bleeding, endometrial cancer, and breast cancer, but elevated the rates of gastrointestinal side effects (67). In this review, the side effects had also been included and reported in some studies. Such side effects were reported following the consumption of higher doses of plant compounds, and certain side effects were widely developed after the consumption of phytochemicals. For example, some studies reported that high doses of genistein can cause gastrointestinal complications $(42,43,49)$.

The main limitation in most clinical trials was the lack of making any comparisons between different doses of herbal derivatives and different populations as well as the lack of control for the confounding factors. According to our review, previous randomized controlled trials addressed very few herbal plants in order to evaluate their pharmacological effects on humans' bone health, most of which were conducted on soy phytochemicals. Therefore, more rigorous research should be done on these plants to evaluate their anti-osteoporotic properties.

\section{Conclusion}

Medicinal plants and their derivatives can be used to enhance bone formation markers, along with antioxidant and anti-inflammatory capacity, but decrease bone resorption biomarkers. Thus, they can be utilized as complementary medicine for osteoporosis, especially in postmenopausal older women. However, further studies are needed in this regard. The plants possess the androgen-like properties that are important for the promotion of bone health. On the other hand, modern pharmaceuticals are also employed to quickly promote none mineral density for people at high risk. In addition, herbal treatments are supportive and slow-acting, and therefore they are suggested to be used for prevention and maintenance purposes rather than fastacting treatments.

Ethical considerations

\section{Nile}

Conflict of Interests

The authors have no conflict of interests.

\section{References}

1. Burge R, Dawson-Hughes B, Solomon DH, Wong JB, King A, Tosteson A. Incidence and economic burden of osteoporosisrelated fractures in the United States, 2005-2025. J Bone Miner Res. 2007;22(3):465-75. doi: 10.1359/jbmr.061113.

2. Jolly JJ, Chin KY, Alias E, Chua KH, Soelaiman IN. Protective effects of selected botanical agents on bone. Int J Environ Res Public Health. 2018;15(5). doi: 10.3390/ijerph15050963.

3. Lötters FJ, van den Bergh JP, de Vries F, Rutten-van Mölken MP. Current and future incidence and costs of osteoporosis-related fractures in the Netherlands: combining claims data with BMD measurements. Calcif Tissue Int. 2016;98(3):235-43. doi: 10.1007/s00223-015-0089-z.

4. Kling JM, Clarke BL, Sandhu NP. Osteoporosis prevention, screening, and treatment: a review. J Womens Health (Larchmt). 2014;23(7):563-72. doi: 10.1089/jwh.2013.4611.

5. Kwon HY, Ha YC, Yoo Jl. Health-related quality of life in accordance with fracture history and comorbidities in Korean patients with osteoporosis. J Bone Metab. 2016;23(4):199-206. doi: 10.11005/jbm.2016.23.4.199.

6. Lems WF, Raterman HG. Critical issues and current challenges in osteoporosis and fracture prevention. An overview of unmet needs. Ther Adv Musculoskelet Dis. 2017;9(12):299-316. doi: 10.1177/1759720x17732562.

7. Vondracek SF, Minne P, McDermott MT. Clinical challenges in the management of osteoporosis. Clin Interv Aging. 2008;3(2):315-29.

8. Ekor M. The growing use of herbal medicines: issues relating to adverse reactions and challenges in monitoring safety. Front Pharmacol. 2014;4:177. doi: 10.3389/fphar.2013.00177.

9. Leung PC, Siu WS. Herbal treatment for osteoporosis: a current review. J Tradit Complement Med. 2013;3(2):82-7. doi: 10.4103/2225-4110.110407.

10. Wang ZQ, Li JL, Sun YL, Yao M, Gao J, Yang Z, et al. Chinese herbal medicine for osteoporosis: a systematic review of randomized controlled trails. Evid Based Complement Alternat Med. 2013;2013:356260. doi: 10.1155/2013/356260.

11. Gunn CA, Weber JL, Kruger MC. Midlife women, bone health, vegetables, herbs and fruit study. The Scarborough Fair study protocol. BMC Public Health. 2013;13:23. doi: 10.1186/14712458-13-23.

12. Gunn CA, Weber JL, McGill AT, Kruger MC. Increased intake of selected vegetables, herbs and fruit may reduce bone turnover in post-menopausal women. Nutrients. 2015;7(4):2499-517. doi: 10.3390/nu7042499.

13. Hwang YC, Jeong IK, Ahn KJ, Chung HY. The effects of Acanthopanax senticosus extract on bone turnover and bone mineral density in Korean postmenopausal women. J Bone Miner Metab. 2009;27(5):584-90. doi: 10.1007/s00774-0090093-3. 
14. Thorup AC, Lambert MN, Kahr HS, Bjerre M, Jeppesen PB. Intake of Novel Red Clover Supplementation for 12 Weeks Improves Bone Status in Healthy Menopausal Women. Evid Based Complement Alternat Med. 2015;2015:689138. doi: 10.1155/2015/689138.

15. Zhao G, Cai D, Dong S, Fan Y. Clinical observation on treatment with the kidney-tonifying prescription in 25 cases of postmenopausal osteoporosis. J Tradit Chin Med. 2003;23(2):103-5.

16. Qiu R, Shen R, Zhang P. Treatment of postmenopausal osteoporosis with yang huo san zi tang--a report of 30 cases. J Tradit Chin Med. 2004;24(2):102-4.

17. Zhang RH, Chen KJ, Lu DX, Zhu XF, Ma XC. A clinical study of Yigu capsule in treating postmenopausal osteoporosis. Chin J Integr Med. 2005;11(2):97-103.

18. Leung PC, Cheng KF, Chan $\mathrm{YH}$. An innovative herbal product for the prevention of osteoporosis. Chin J Integr Med. 2011;17(10):744-9. doi: 10.1007/s11655-011-0876-y.

19. Yang F, Tang DZ, Cui XJ, Holz JD, Bian Q, Shi Q, et al. Classic yin and yang tonic formula for osteopenia: study protocol for a randomized controlled trial. Trials. 2011;12:187. doi: 10.1186/1745-6215-12-187.

20. Zhu HM, Qin L, Garnero P, Genant HK, Zhang G, Dai K, et al. The first multicenter and randomized clinical trial of herbal Fufang for treatment of postmenopausal osteoporosis. Osteoporos Int. 2012;23(4):1317-27. doi: 10.1007/s00198011-1577-2.

21. Yang YP, Shuai B, Shen L, Xu XJ, Ma C, Lv L. Effect of Qing'e formula on circulating sclerostin levels in patients with postmenopausal osteoporosis. J Huazhong Univ Sci Technolog Med Sci. 2015;35(4):525-30. doi: 10.1007/s11596-015-14648.

22. Shi ZY, Zhang XG, Li CW, Liu K, Liang BC, Shi XL. Effect of traditional Chinese medicine product, QiangGuYin, on bone mineral density and bone turnover in Chinese postmenopausal osteoporosis. Evid Based Complement Alternat Med. 2017;2017:6062707. doi: 10.1155/2017/6062707.

23. Alshafei MM, Kassem SS, Ramadan MM, Hanafi EM, Saber MM, Saber LM, et al. Innovative Food Supplement of Functional Seeds Mixture Improved Bone Mineral Density in Menopausal Egyptian Women. Int J Pharmacol. 2017;13(8):1055-62. doi: 10.3923/ijp.2017.1055.1062.

24. Guo N, Li B, Jiang X. The efficacy of a phytoestrogen-rich chinese medicine on senile osteoporosis. Farmacia. 2018;66(6):107680. doi: 10.31925/FARMACIA.2018.6.23.

25. Li ZR, Cheng LM, Wang KZ, Yang NP, Yang SH, He W, et al. Herbal Fufang Xian Ling Gu Bao prevents corticosteroidinduced osteonecrosis of the femoral head-A first multicentre, randomised, double-blind, placebo-controlled clinical trial. J Orthop Translat. 2018;12:36-44. doi: 10.1016/j. jot.2017.11.001.

26. Lin J, Zhu J, Tian FB, Chen L, ZhangY, WangY, et al. Effects of Ziyin Jianghuo Ningxin decoction plus dehydroepiandrosterone and femoston in treatment of patients with menopausal symptoms. J Tradit Chin Med. 2018;38(5):787-96. doi: 10.1016/S02546272(18)30920-8.

27. Wattanathorn J, Somboonporn W, Sungkamanee S, Thukummee W, Muchimapura S. A double-blind placebocontrolled randomized trial evaluating the effect of polyphenol-rich herbal congee on bone turnover markers of the perimenopausal and menopausal women. Oxid Med Cell Longev. 2018;2018:2091872. doi: 10.1155/2018/2091872.

28. Yun GW, Kang JH, Lee $\mathrm{H}$. Effects of Korean herbal medicine (Cheong-A-Won) for treatment of bone mineral density in women with osteoporosis: a randomized, double blind, placebo controlled trial. Eur J Integr Med. 2018;20:84-9. doi: 10.1016/j.eujim.2018.04.009.

29. Zheng Y, Wang X, Zhang ZK, Guo B, Dang L, He B, et al. Bushen Yijing Fang reduces fall risk in late postmenopausal women with osteopenia: a randomized double-blind and placebo-controlled trial. Sci Rep. 2019;9(1):2089. doi: 10.1038/s41598-018-38335-3.

30. Scheiber MD, Liu JH, Subbiah MT, Rebar RW, Setchell KD. Dietary inclusion of whole soy foods results in significant reductions in clinical risk factors for osteoporosis and cardiovascular disease in normal postmenopausal women. Menopause. 2001;8(5):384-92. doi: 10.1097/00042192200109000-00015.

31. Chiechi LM, Secreto G, D'Amore M, Fanelli M, Venturelli E, Cantatore F, et al. Efficacy of a soy rich diet in preventing postmenopausal osteoporosis: the Menfis randomized trial. Maturitas. 2002;42(4):295-300. doi: 10.1016/s03785122(02)00158-5.

32. Chen YM, Ho SC, Lam SS, Ho SS, Woo JL. Beneficial effect of soy isoflavones on bone mineral content was modified by years since menopause, body weight, and calcium intake: a double-blind, randomized, controlled trial. Menopause. 2004;11(3):246-54. doi: 10.1097/01.gme.0000094394.59028.46.

33. Ye YB, Tang XY, Verbruggen MA, Su YX. Soy isoflavones attenuate bone loss in early postmenopausal Chinese women: a single-blind randomized, placebo-controlled trial. Eur J Nutr. 2006;45(6):327-34. doi: 10.1007/s00394-006-0602-2.

34. Wu J, Oka J, Ezaki J, Ohtomo T, Ueno T, Uchiyama S, et al. Possible role of equol status in the effects of isoflavone on bone and fat mass in postmenopausal Japanese women: a double-blind, randomized, controlled trial. Menopause. 2007;14(5):866-74. doi: 10.1097/gme.0b013e3180305299.

35. Shedd-Wise KM, Alekel DL, Hofmann H, Hanson KB, Schiferl DJ, Hanson LN, et al. The soy isoflavones for reducing bone loss study: 3-yr effects on PQCT bone mineral density and strength measures in postmenopausal women. J Clin Densitom. 2011;14(1):47-57. doi: 10.1016/j.jocd.2010.11.003.

36. Lee H, Choue R, Lim H. Effect of soy isoflavones supplement on climacteric symptoms, bone biomarkers, and quality of life in Korean postmenopausal women: a randomized clinical trial. Nutr Res Pract. 2017;11(3):223-31. doi: 10.4162/ nrp.2017.11.3.223.

37. Tit DM, Bungau S, lovan C, Nistor Cseppento DC, Endres L, Sava C, et al. Effects of the hormone replacement therapy and of soy isoflavones on bone resorption in postmenopause. J Clin Med. 2018;7(10). doi: 10.3390/jcm7100297.

38. Sathyapalan T, Aye M, Rigby AS, Fraser WD, Thatcher NJ, Kilpatrick ES, et al. Soy reduces bone turnover markers in women during early menopause: a randomized controlled trial. J Bone Miner Res. 2017;32(1):157-64. doi: 10.1002/ jbmr.2927.

39. Levis S, Strickman-Stein N, Doerge DR, Krischer J. Design and baseline characteristics of the soy phytoestrogens as replacement estrogen (SPARE) study--a clinical trial of the effects of soy isoflavones in menopausal women. Contemp Clin Trials. 2010;31(4):293-302. doi: 10.1016/j.cct.2010.03.007.

40. Roudsari AH, Tahbaz F, Hossein-Nezhad A, Arjmandi B, Larijani B, Kimiagar SM. Assessment of soy phytoestrogens' effects on bone turnover indicators in menopausal women with osteopenia in Iran: a before and after clinical trial. Nutr J. 2005;4:30. doi: 10.1186/1475-2891-4-30.

41. Kok L, Kreijkamp-Kaspers S, Grobbee DE, van der Schouw YT. Design and baseline characteristics of a trial on health effects of soy protein with isoflavones in postmenopausal women. Maturitas. 2004;47(1):21-9. doi: 10.1016/s0378- 
5122(03)00243-3.

42. Marini H, Minutoli L, Polito F, Bitto A, Altavilla D, Atteritano M, et al. Effects of the phytoestrogen genistein on bone metabolism in osteopenic postmenopausal women: a randomized trial. Ann Intern Med. 2007;146(12):839-47. doi: 10.7326/00034819-146-12-200706190-00005.

43. Atteritano M, Pernice F, Mazzaferro S, Mantuano S, Frisina A, D'Anna R, et al. Effects of phytoestrogen genistein on cytogenetic biomarkers in postmenopausal women: 1 year randomized, placebo-controlled study. Eur J Pharmacol. 2008;589(1-3):22-6. doi: 10.1016/j.ejphar.2008.04.049.

44. Marini H, Bitto A, Altavilla D, Burnett BP, Polito F, Di Stefano $\mathrm{V}$, et al. Breast safety and efficacy of genistein aglycone for postmenopausal bone loss: a follow-up study. J Clin Endocrinol Metab. 2008;93(12):4787-96. doi: 10.1210/jc.2008-1087.

45. Atteritano M, Mazzaferro S, Frisina A, Cannata ML, Bitto A, D'Anna R, et al. Genistein effects on quantitative ultrasound parameters and bone mineral density in osteopenic postmenopausal women. Osteoporos Int. 2009;20(11):194754. doi: 10.1007/s00198-009-0883-4.

46. Weaver CM, Martin BR, Jackson GS, McCabe GP, Nolan JR, McCabe LD, et al. Antiresorptive effects of phytoestrogen supplements compared with estradiol or risedronate in postmenopausal women using (41) Ca methodology. J Clin Endocrinol Metab. 2009;94(10):3798-805. doi: 10.1210/ jc.2009-0332.

47. Lappe J, Kunz I, Bendik I, Prudence K, Weber P, Recker R, et al. Effect of a combination of genistein, polyunsaturated fatty acids and vitamins D3 and K1 on bone mineral density in postmenopausal women: a randomized, placebo-controlled, double-blind pilot study. Eur J Nutr. 2013;52(1):203-15. doi: 10.1007/s00394-012-0304-x.

48. Pawlowski JW, Martin BR, McCabe GP, McCabe L, Jackson GS, Peacock M, et al. Impact of equol-producing capacity and soy-isoflavone profiles of supplements on bone calcium retention in postmenopausal women: a randomized crossover trial. Am J Clin Nutr. 2015;102(3):695-703. doi: 10.3945/ ajcn.114.093906.

49. Arcoraci V, Atteritano M, Squadrito F, D'Anna R, Marini H, Santoro D, et al. Antiosteoporotic Activity of Genistein Aglycone in Postmenopausal Women: Evidence from a PostHoc Analysis of a Multicenter Randomized Controlled Trial. Nutrients. 2017;9(2). doi: 10.3390/nu9020179.

50. Yoles I, Yogev Y, Frenkel Y, Nahum R, Hirsch M, Kaplan B. Tofupill/Femarelle (DT56a): a new phyto-selective estrogen receptor modulator-like substance for the treatment of postmenopausal bone loss. Menopause. 2003;10(6):522-5. doi: 10.1097/01.gme.0000064864.58809.77.

51. Zhang G, Qin L, Shi Y. Epimedium-derived phytoestrogen flavonoids exert beneficial effect on preventing bone loss in late postmenopausal women: a 24-month randomized, double-blind and placebo-controlled trial. J Bone Miner Res. 2007;22(7):1072-9. doi: 10.1359/jbmr.070405.

52. Lamb JJ, Holick MF, Lerman RH, Konda VR, Minich DM, Desai A, et al. Nutritional supplementation of hop rho iso-alpha acids, berberine, vitamin $\mathrm{D}(3)$, and vitamin $\mathrm{K}(1)$ produces a favorable bone biomarker profile supporting healthy bone metabolism in postmenopausal women with metabolic syndrome. Nutr Res. 2011;31(5):347-55. doi: 10.1016/j.nutres.2011.03.016.

53. Granado-Lorencio F, Lagarda MJ, Garcia-López FJ, SánchezSiles LM, Blanco-Navarro I, Alegría A, et al. Effect of betacryptoxanthin plus phytosterols on cardiovascular risk and bone turnover markers in post-menopausal women: a randomized crossover trial. Nutr Metab Cardiovasc Dis. 2014;24(10):10906. doi: 10.1016/j.numecd.2014.04.013.

54. Brink E, Coxam V, Robins S, Wahala K, Cassidy A, Branca F. Long-term consumption of isoflavone-enriched foods does not affect bone mineral density, bone metabolism, or hormonal status in early postmenopausal women: a randomized, double-blind, placebo controlled study. Am J Clin Nutr. 2008;87(3):761-70. doi: 10.1093/ajcn/87.3.761.

55. Levis S, Strickman-Stein N, Ganjei-Azar P, Xu P, Doerge DR, Krischer J. Soy isoflavones in the prevention of menopausal bone loss and menopausal symptoms: a randomized, doubleblind trial. Arch Intern Med. 2011;171(15):1363-9. doi: 10.1001/archinternmed.2011.330.

56. Tai TY, Tsai KS, Tu ST, Wu JS, Chang Cl, Chen CL, et al. The effect of soy isoflavone on bone mineral density in postmenopausal Taiwanese women with bone loss: a 2-year randomized double-blind placebo-controlled study. Osteoporos Int. 2012;23(5):1571-80. doi: 10.1007/s00198-011-1750-7.

57. Lambert MNT, Thybo CB, Lykkeboe S, Rasmussen LM, Frette $X$, Christensen LP, et al. Combined bioavailable isoflavones and probiotics improve bone status and estrogen metabolism in postmenopausal osteopenic women: a randomized controlled trial. Am J Clin Nutr. 2017;106(3):909-20. doi: 10.3945/ ajcn.117.153353.

58. Hasani-Ranjbar S, Jouyandeh Z, Qorbani M, Hemmatabadi M, Larijani B. The effect of semelil (angipars(R)) on bone resorption and bone formation markers in type 2 diabetic patients. Daru. 2012;20(1):84. doi: 10.1186/2008-2231-20-84.

59. Alekel DL, Van Loan MD, Koehler KJ, Hanson LN, Stewart JW, Hanson KB, et al. The soy isoflavones for reducing bone loss (SIRBL) study: a $3-y$ randomized controlled trial in postmenopausal women. Am J Clin Nutr. 2010;91(1):218-30. doi: 10.3945/ajcn.2009.28306.

60. Leali PT, Muresu F, Melis A, Ruggiu A, Zachos A, Doria C. Skeletal fragility definition. Clin Cases Miner Bone Metab. 2011;8(2):11-3.

61. Ji MX, Yu Q. Primary osteoporosis in postmenopausal women. Chronic Dis Transl Med. 2015;1(1):9-13. doi: 10.1016/j. cdtm.2015.02.006.

62. Tella SH, Gallagher JC. Prevention and treatment of postmenopausal osteoporosis. J Steroid Biochem Mol Biol. 2014;142:155-70. doi: 10.1016/j.jsbmb.2013.09.008.

63. Bartl R, Frisch B. Osteoporosis: diagnosis, prevention, therapy. Berlin: Springer Science \& Business Media; 2009.

64. Nadia ME, Nazrun AS, Norazlina M, Isa NM, Norliza M, Ima Nirwana S. The anti-inflammatory, phytoestrogenic, and antioxidative role of Labisia pumila in prevention of postmenopausal osteoporosis. Adv Pharmacol Sci. 2012;2012:706905. doi: 10.1155/2012/706905.

65. Jia M, Nie Y, Cao DP, Xue YY, Wang JS, Zhao L, et al. Potential antiosteoporotic agents from plants: a comprehensive review. Evid Based Complement Alternat Med. 2012;2012:364604. doi: 10.1155/2012/364604.

66. Sungkamanee S, Wattanathorn J, Muchimapura S, Thukhammee W. Antiosteoporotic effect of combined extract of Morus alba and Polygonum odoratum. Oxid Med Cell Longev. 2014;2014:579305. doi: 10.1155/2014/579305.

67. Tempfer CB, Froese G, Heinze G, Bentz EK, Hefler LA, Huber JC. Side effects of phytoestrogens: a meta-analysis of randomized trials. Am J Med. 2009;122(10):939-46.e9. doi: 10.1016/j.amjmed.2009.04.018. 